\title{
Development of a weather-based model for Botrytis leaf blight of onion
}

\author{
Leandro Luiz Marcuzzo ${ }^{1}$, Roberto Haveroth ${ }^{1}$
}

\begin{abstract}
${ }^{1}$ Instituto Federal Catarinense - IFC / Rio do Sul Campus, CP 441, CEP 89163-356, Rio Sul, SC. Autor para correspondência: Leandro Luiz Marcuzzo (marcuzzo@ifc-riodosul.edu.br) Data de chegada: 16/09/2014. Aceito para publicação em: 26/08/2015.
\end{abstract}

$10.1590 / 0100-5405 / 2034$

\section{ABSTRACT}

Marcuzzo, L.L.; Haveroth, R. Development of a weather-based model for Botrytis leaf blight of onion. Summa Phytopathologica, v.42, n.1, p.92-93, 2016.

In the present study, onion plants were tested under controlled conditions for the development of a climate model based on the influence of temperature $\left(10,15,20\right.$ and $\left.25^{\circ} \mathrm{C}\right)$ and leaf wetness duration $(6,12$, 24 and 48 hours) on the severity of Botrytis leaf blight of onion caused by Botrytis squamosa. The relative lesion density was influenced by temperature and leaf wetness duration $(\mathrm{P}<0.05)$. The disease was most severe at $20^{\circ} \mathrm{C}$. Data were subjected to nonlinear regression analysis. Beta generalized function was used to adjust severity and temperature data, while a logistic function was chosen to represent the effect of leaf wetness on the severity of Botrytis leaf blight. The response surface obtained by the product of two functions was expressed as ES $=0.008192 *\left(\left((x-5)^{1.01089}\right)\right.$ $\left.*\left((30-x)^{1.19052}\right)\right) *(0.33859 /(1+3.77989 * \exp (-0.10923 * y)))$, where ES represents the estimated severity value $(0.1)$; $\mathrm{x}$, the temperature $\left({ }^{\circ} \mathrm{C}\right)$; and $\mathrm{y}$, the leaf wetness (in hours). This climate model should be validated under field conditions to verify its use as a computational system for the forecasting of Botrytis leaf blight in onion.

Keywords: Allium cepa, Botrytis squamosa, epidemiology, disease forecasting

\section{RESUMO}

Marcuzzo, L.L.; Haveroth, R. Desenvolvimento de um modelo climático para a queima das pontas da cebola. Summa Phytopathologica, v.42, n.1, p.92-93, 2016.

No presente trabalho foram estudadas, em condições controladas para o desenvolvimento de um modelo climático baseado na influência da temperatura $\left(10,15,20\right.$ e $\left.25^{\circ} \mathrm{C}\right)$ e da duração do molhamento foliar (6, 12, 24 e 48 horas) na severidade da queima das pontas da cebola incitada por Botrytis squamosa. A densidade relativa de lesões foi influenciada pela temperatura e pela duração do molhamento foliar $(\mathrm{P}<0,05)$. A doença foi mais severa na temperatura de $20^{\circ} \mathrm{C}$. Os dados foram submetidos à análise de regressão não linear. A função beta generalizada foi usada para ajuste dos dados de severidade e temperatura, enquanto uma função logística foi escolhida para representar o efeito do molhamento foliar na severidade queima das pontas. A superfície de resposta obtida pelo produto das duas funções foi expressa por SE $=0,008192 *(((x$ $\left.\left.5)^{1,01089}\right) *\left((30-x)^{1,19052}\right)\right) *(0,33859 /(1+3,77989 * \exp (-0,10923 * y)))$, onde $\mathrm{SE}$, representa o valor da severidade estimada $(0,1) ; x$, a temperatura $\left({ }^{\circ} \mathrm{C}\right)$ e $y$, o molhamento foliar (horas). Este modelo climático deverá ser validado em condições de campo para aferir o seu emprego como um sistema de previsão computacional para a queima das pontas da cebola.

Palavras-chave: Allium cepa, Botrytis squamosa, epidemiologia, previsão de doenças

Botrytis leaf blight of onion, caused by Botrytis squamosa, is an important disease for the onion crop throughout Brazil since it can reduce by $50 \%$ the seedlings used for transplanting, and the number of surviving leaves per plant is small (10), indirectly affecting the normal development of the bulb. Typically, temperatures close to $20^{\circ} \mathrm{C}$ and periods longer than nine hours of leaf wetness favor its development (2).

The symptoms are small silver halos and isolated spots on the leaf surface, but without sporulation. Insofar as the spots develop, necrosis occurs on the leaf tips at intensity directly proportional to the number of lesions on the leaf. Therefore, typical symptoms are dried leaf and sporulation where the pathogen occurs $(6,10)$. The disease is more aggressive in seedlings than in older plants. For disease control, protective products such as captan and the mixture of copper oxychloride + mancozeb (1) are registered but they are not efficient after the pathogen infection.

The establishment of a disease depends on the interaction among environment, host, and pathogen. Environmental factors such as temperature and leaf wetness are critical to the epidemiological process.
Nowadays, there are mathematical models developed to predict the best conditions for the outset of diseases (4). These models have been used in some plant disease systems such as soybean rust, downy mildew, leaf spot in apple Glomerella, and Fusarium wheat blight in wheat (7). Predictive models of plant diseases are simplified representations of the reality and provide the most favorable conditions for the beginning, or the future development, of a disease, alerting to the time for preventive control (3).

The aim of this study was to develop a climate model based on the relationship between different values of temperature and leaf wetness duration on the severity of Botrytis leaf blight of onion.

The study was conducted at "Instituto Federal Catarinense - IFC"/ Rio Sul Campus, SC. Onion seedlings of the cultivar Epagri 352 Bola Precoce were grown in beds to 60 days of age. When presenting three expanded leaves, the plants were transplanted into cups containing a $300-\mathrm{mL}$ mixture of substrate and non-sterile soil. The plants were then left for 24 hours in a humid chamber and, immediately after, the leaves were cleaned with cotton wool to remove cerosity. Plants were 
then inoculated with a spore suspension of B. squamosa that had been cultivated for eight days in PDA, at a concentration of $1.75 \times 10^{6}$ of spores $/ \mathrm{mL}$, according to the method of spraying up to run-in, using a manual atomizer. After inoculation, the plants were placed on a plastic tray containing a layer of 0.5 centimeters of sterile water and wrapped with a clean moistened plastic bag. The trays were transferred to BOD incubators with temperatures adjusted to $10,15,20$, and $25^{\circ} \mathrm{C}, 12$ hours of photoperiod, constant light, and 6, 12, 24, and 48 hours of continuous moisture. At the end of each wetness period, plants were removed and dried with heated forced air and transferred to a room at a $22^{\circ} \mathrm{C}$ airconditioned environment. The disease severity was evaluated based on the percentage of dry leaf in proportion to the total growth of the three leaves on the fifteen day after inoculation.

A completely randomized design with five replicates was used for each combination between temperature and wetness. Each replicate consisted of one plant, and the average severity values of the three inoculated leaves were used to determine the relationship between leaf wetness duration and temperature on the disease severity.

The response surface is a result of the product of two functions. The beta generalized function expressed by the equation $y=b 1 *(T-b 2)$ $\left.\mathrm{b} 4 *(\mathrm{~b} 3-\mathrm{T})^{\mathrm{b} 5}\right)$ was used to determine the severity of the response to different temperatures, where $b 2$ is the parameter estimator of minimum temperature; $b 3$ is the parameter estimator of maximum temperature; b1, b4 and b5 are parameters of the equation; $\mathrm{T}$ is the independent variable, in this case, the temperature; and y is the estimated severity. The beta generalized function used to model the effect of temperature on the severity expresses the boundary between the maximum and the minimum temperature by the introduction of the proposed parameters in the model and demonstrates that the temperature increase directly affects the disease development until a specific limit is reached, after which a sharp decrease (5) occurs.

The logistic function expressed by the equation: $y=y m a x /(1+\exp (-$ $\ln \left(\mathrm{yo} /(\mathrm{ymax}-\mathrm{yo})-\mathrm{r}^{*} \mathrm{x}\right)$ is used to correlate with the severity and the leaf wetness duration, where $y$ is the predicted severity, ymax is the maximum disease severity, $\ln$ (yo / (ymax-yo) refers to the function of the proportion of disease in the first observation, $r$ corresponds to a rate and $x$ is the time of wetness. This function represents leaf wetness and severity because as the number of hours of leaf wetness increases, the disease severity increases, if temperature conditions are favorable (9).

The function $\mathrm{ES}=0.008192 *\left(\left((x-5)^{1.01089}\right) *\left((30-x)^{1.19052}\right)\right) *$ $(0.33859 /(1+3.77989 * \exp (-0.10923 * y)))$, where $\mathrm{ES}=$ represents the value of the estimated severity $(0.1)$; $x$, the temperature $\left({ }^{\circ} \mathrm{C}\right)$ and $y$, the wetness period, has been established as an appropriate mathematical model to represent the response surface (Figure 1).

There was a gradual increase in the disease while the temperature increased from 15 to $20^{\circ} \mathrm{C}$ for a period of continuous leaf wetness. This effect was also observed by Alderman \& Lacy (2): the production of lesions had greater occurrence at $20^{\circ} \mathrm{C}$ than below $15^{\circ} \mathrm{C}$. On the other hand, when the temperature changed from 20 to $25^{\circ} \mathrm{C}$, there was a decrease in severity, coinciding with the results obtained by Sutton et al. (8). Both references above do not describe a mathematical model to explain this effect. In this paper, in the interval between 15 and $20^{\circ} \mathrm{C}$, there was a remarkable increase in severity when the leaf wetness duration exceeded 10 hours. However, at $25^{\circ} \mathrm{C}$, symptoms did not appear, even after 40 hours of wetness.

In future experiments in the field, conducted with natural Botrytis

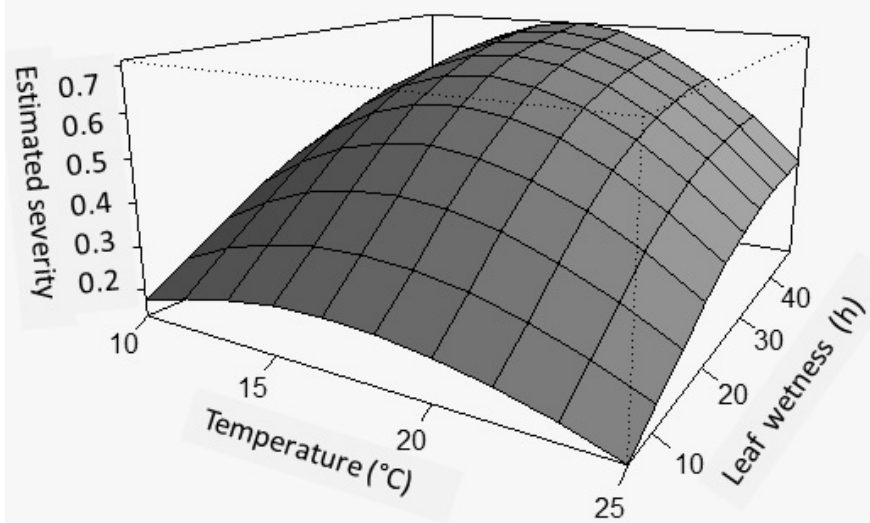

Figure 1. Estimated severity of Botrytis leaf blight (Botrytis squamosa) of onion Epagri 352 Bola Precoce based on the interaction between temperature and leaf wetness, represented by ES $=0.008192 *(((x-$ $\left.\left.5)^{1.01089}\right) *\left((30-x)^{1.19052}\right)\right) *(0.33859 /(1+3.77989 * \exp (-0.10923 * y)))$ where: ES = estimated severity $(0.1) ; \mathrm{x}=$ temperature $\left({ }^{\circ} \mathrm{C}\right)$; $\mathrm{y}=$ leaf wetness (h). IFC / Rio do Sul Campus, 2014.

leaf blight, the daily value of estimated severity will be determined. The estimated severity value will be used as an indicator of the time of fungicide application for onion culture, aiming to serve as a control system of the disease.

The information obtained from the interaction between temperature and leaf wetness duration allows greater understanding of the epidemiology of this disease and can be used to develop a climate model for computerized forecasting of Botrytis leaf blight of onion.

\section{REFERENCES}

1. AGROFIT. Sistema de agrotóxicos fitossanitários. Disponível em: $<\mathrm{http}: / /$ agrofit.agricultura.gov.br/agrofit_cons/principal_agrofit_cons $>$. Acesso em: 24 abr. 2014.

2. Alderman, S.C.; Lacy, M.L. Influence of dew period and temperature on infection of leaves by dry conidia of Botrytis squamosa. Phytopathology, St. Paul, v.73, n.8. p.1020-1023, 1983.

3. Barreto, M.; Vale, F.X.R; Paul, P.A.; Scaloppi, E.A.G.; Andrade, D. F. A. Sistemas de previsão e estação de aviso. In: Vale, F.X.R.; Jesus Junior, W.C.; Zambolim, L. Epidemiologia aplicada ao manejo de doenças de plantas. Belo Horizonte: Perffil, 2004. p.243-266.

4. Bergamim Filho, A.; Amorim, L. Doenças de plantas tropicais: epidemiologia e controle econômico. São Paulo:Ceres, 1996. 299p.

5. Hau, B. Analytic modes of plant disease in a changing environmental. Annual Review of Phytopathology, Palo Alto, v.28, p. 221-245, 1990.

6. Nunes, M.E.T.; Kimati, H. Doenças do alho e cebola. In: Kimati, H.; Amorim, L.; Bergamin Filho, A.; Camargo, L.E.A. Manual de fitopatologia. doenças de plantas cultivadas. 4. ed. São Paulo: Ceres, 1997. v.2, Cap. 7, p.55-69.

7. Reis, E.M. Previsão de doenças de plantas. Passo Fundo:UPF, 2004. 316p.

8. Sutton, J.C.; James, T.W.D.; Rowel, P.M. Botcast: a forecasting system to time initial fungicide spray for managing botrytis leaf blight of onions. Agriculture, ecosystems and environment, Amsterdam, v.18, p.123-143, 1986.

9. Vale, F.X.R.; Zambolim, L. Influência da temperatura e da umidade nas epidemias de doenças de planta. Revisão Anual de Patologia de Plantas, Passo Fundo, v.4, p.149-207, 1996.

10. Wordell Filho, J.A.; Boff, P. Queima acizentada. In: Wordell Filho, J. A.; Rowe, E.; Gonçalves, P.A.; Debarba, J.F.; Boff, P.; Thomazelli, L.F. Manejo Fitossanitário na cultura da cebola. Florianópolis: EPAGRI, p.19-30, 2006. 